\title{
Effect of Sludge Addition on Biological Properties of Soil under Rice Cultivation
}

\author{
Anil Kumar Verma ${ }^{1 *}$, Raj Dev Singh ${ }^{1}$, Brijesh Yadav², \\ Ravi Kumar Meena ${ }^{1}$ and Chiranjeev Kumawat ${ }^{1}$
}

\author{
${ }^{1}$ Division of Soil Science and Agricultural Chemistry, ${ }^{2}$ Division of Agricultural Physics, ICAR- \\ Indian Agricultural Research Institute, New Delhi 110012, India \\ *Corresponding author
}

\section{A B S T R A C T}

\begin{tabular}{|c|}
\hline Keywords \\
\hline $\begin{array}{l}\text { Alkaline soil, } \\
\text { biological } \\
\text { properties, } \\
\text { Sludge, } \\
\text { Rice }\end{array}$ \\
\hline Article Info \\
\hline $\begin{array}{l}\text { Accepted: } \\
25 \text { April } 2017 \\
\text { Available Online: } \\
10 \text { May } 2017\end{array}$ \\
\hline
\end{tabular}

A pot experiment was conducted to study the effect of sludge application on metal uptake and biological properties of soil by basmati rice (Oryza sativa, var Pusa Basmati 1121) grown on alkaline soil of IARI farm. In this study, the sludge was collected from Okhla sewage treatment plant, South Delhi. Sludge was added @ 0,40,80, 120, 160, and $200 \mathrm{~g}$ per pot of soil, which are equivalent to field application of $0,20,40,60,80$, and $100 \mathrm{t} \mathrm{ha}^{-1}$. All six treatments were replicated thrice and experiments were laid out in completely randomised design. The result shows that all the biological properties viz. acid phosphatase, alkaline phosphatase and fluorescein diacetate activity (FDA) were increased for all sludge treated pots over control. Therefore, results can be concluded as sludge is a good source of plant nutrients, nitrogen $(\mathrm{N})$, phosphorus $(\mathrm{P})$, potassium $(\mathrm{K})$, sulphur $(\mathrm{S})$ and two important micronutrients i.e. of zinc $(\mathrm{Zn})$ and iron $(\mathrm{Fe})$ and also helps in improvement in fertility and important biological properties of soil.

\section{Introduction}

Sewage sludge is a liquid-solid residue resulting from the treatment of urban or industrial effluents. The application of sewage sludge in agriculture as a source of plant nutrients and as soil conditioner is increasingly being favoured by the farmers not only in our country but across the globe. The total sewage generated from urban areas was estimated 62,000 million litres per day (MLD) while the treatment capacity across India is only 23,277 MLD, or $37 \%$ of sewage generated (CPCB, 2016). Although sewage sludge having a relatively variable composition, it is rich in organic matter, nitrogen $(\mathrm{N})$, phosphorus $(\mathrm{P})$ and sulphur $(\mathrm{S})$ potassium $(\mathrm{K})$, calcium $(\mathrm{Ca})$ and magnesium (Mg)(Gray, 2010; Mtshali et al.,2014; Golui et al., 2014). It can be considered as a viable alternative for fertilizer, beside it act as a soil conditioner. The properties and composition of sewage sludge may vary with the sources and season. Metal concentrations in sewage sludge vary widely depends mainly on its origin, for example, industrial wastes usually 
contain higher levels of heavy metals than domestic wastes. Metal contents in sludge also depend on the types of sewage treatment process. Organic matter-metal associations also differ between aerobically and anaerobically digested sludge (Doelsch et al., 2006). Characterization of the sewage sludge as a source of plant nutrients becomes very important due to the heterogeneity and variability in the composition to predict its fitness for use in agriculture. Addition of sludge to agricultural soil is associated with recycling of important major plant nutrients such as $\mathrm{N}, \mathrm{P}, \mathrm{K}$ and $\mathrm{S}$ (Nandhakumar et al., 1998; Martinez et al., 2002). More importantly, these waste materials add substantial amount of organic matter, besides improving physical properties of soil like bulk density, porosity, water holding capacity, hydraulic conductivity and aggregate stability (Singh and Agrawal, 2008). Cation exchange capacity (CEC) of soil has been reported to improve by addition of sewage sludge (Ghahdarijani et al., 2015). Further, application of sludge is capable of changing soil $\mathrm{pH}$, hence can be used in reclamation of acid and sodic soil (Tsalidas et al., 1995). Significant enhancement in microbial biomass carbon, dehydrogenase activity and aggregate associated organic matter has been reported particularly when higher amount of sludge was applied (Mondal et al., 2015).

Rice is one of the major staple food crops in India. Currently, 43 million ha of land is under the cultivation of this crop in our country with the total production of 104 million tonnes (Commodity profile for rice April, 2016). As such, there is very little information related to impact of sludge application on changes in soil biological properties under rice crop (Singh and Agrawal, 2010b; Latare et al., 2014). It can be expected that impact of sludge application, particularly under transplanted rice (submerged condition) will be quite different than under other aerobically grown crops. Keeping this in view, present study was undertaken to assess the impact of sludge addition on important soil biological properties under rice cultivation.

\section{Materials and Methods}

\section{Location and collection of soil and sludge samples}

To achieve the objectives of the present investigation surface $(0-15 \mathrm{~cm})$ soil samples were collected from experimental farm of IARI $\left(28^{\circ} 30^{\prime} \mathrm{N}, 77^{\circ} 10^{\prime} \mathrm{E} ; 250 \mathrm{~m}\right.$ amsl), New Delhi. Soil of IARI farm belongs to Typic Haplustept in sub-tropical semi-arid agroclimatic zone (precipitation $650 \mathrm{~mm}$ ) of Upper Gangetic Plain and sludge sample was collected from sewage treatment plants of Delhi viz. Okhla in the month of March, 2015. The treatment capacity of Okhla is 170 million gallon per day (MGD).

\section{Characterization of soil and sludge}

Soil samples were air dried ground and sieved with a $2-\mathrm{mm}$ nylon sieve. Soil samples were dried, ground, and passed through 2-mm sieve. Soil $\mathrm{pH}$ and electrical conductivity (EC) was measured in the suspension (soil/water, 2:1) according to Datta et al., (1997). Soil texture was determined by the hydrometer method (Bouyoucos, 1962). Organic carbon content in soil was determined by the wet digestion method (Walkley and Black, 1934). Available nitrogen in soil was determined by alkaline potassium permanganate $(\mathrm{KMnO} 4)$ (Subbiah and Asija, 1956). For available $\mathrm{P}$, and $\mathrm{K}$, soil was extracted with $0.5 \mathrm{M} \mathrm{NaHOC} 3$ (Olsen $e t$ al., 1954), and $1 \mathrm{M}$ NH4OAC (Jackson, 1973). For heavy metal analysis, the soil samples were extracted with0.005 M DTPA (Lindsay and Norvell, 1978) and metals in the extract were determined by ICP-MS. Arsenic 
was determined by extracting the soil sample with $0.5 \mathrm{M} \mathrm{NaHCO} 3 \mathrm{pH} 8.5$ (Olsen et al., 1954) and content of As in the extract was measured by ICP-MS. Sludge samples were air-dried, ground and sieved to pass through 2 $\mathrm{mm}$ sieve. The processed and homogenized sludge was chemically analysed. Sludge collected from Okhla was used in pot experiment in since high amount of sludge is generated from Okhla among these treatment plants. Sludge samples were analysed for $\mathrm{pH}$ (sludge/water, 1:5) and electrical conductivity following standard procedures (Jackson, 1973). Organic carbon, total nitrogen and sulphur were determined by dry combustion method (Nelson and Sommers, 1982) in CHNS analyser (Euro Vector make, Euro EA3000 model).Sludge samples were dried at $60{ }^{\circ} \mathrm{C}$ in hot air oven, ground, and digested in HNO3 (Merck KGaA, 64271 Darmstadt Germany) using microwave (Multiwave ECO, Anton Paar). Total $\mathrm{Zn}, \mathrm{Cu}, \mathrm{Fe}, \mathrm{Mn}, \mathrm{Ni}, \mathrm{Cd}$, $\mathrm{Pb}$ and $\mathrm{As}$ in digest was determined with ICPMS (PerkinElmer Nex-ION 300).Phosphorus and potassium content in the digest was determined following ascorbic acid method (Watanabe and Olsen, 1965) using spectrometer and flame photometer, respectively. Initial characteristics of experimental soils and sludge were given in Table 1.

\section{Pot experiment}

A pot experiment was conducted to study the effect of sludge application on metal uptake by basmati rice (Oryza sativa, var Pusa Basmati 1121) grown on alkaline soils. Plastic pots of $5 \mathrm{~kg}$ capacity were filled with $4 \mathrm{~kg}$ of IARI soil. A uniform dose of $\mathrm{N}: \mathrm{P}_{2} \mathrm{O}_{5}: \mathrm{K}_{2} \mathrm{O}$ @ 75: 40: $30 \mathrm{mg} \mathrm{kg}^{-1}$ soils were added in solution form to the soil of each pot through urea, potassium dihydrogen phosphate and muriate of potash. Half of $\mathrm{N}$ and full dose of $\mathrm{P}$ and $\mathrm{K}$ were applied at the time of transplanting of rice and remaining $\mathrm{N}$ fertilizer was applied in two equal splits at tillering and flower initiation stage. The sludge collected from Okhla was added @ 0, 40, 80, 120, 160, and $200 \mathrm{~g}$ per pot of soil, which are equivalent to field application of 0 , 20, 40, 60, 80, and $100 \mathrm{t} \mathrm{ha}^{-1}$. All six treatments were replicated thrice and experiments were laid out in completely randomised design. The soil in each pot was irrigated with tap water and the pots were maintained the submerged condition during whole crop growth period. Simultaneously, a tray $(45 \times 30 \times 15 \mathrm{~cm} 3)$ was filled with processed IARI soil. Soil was irrigated with tap water to maintain moisture content at field capacity and kept overnight. About $10 \mathrm{~g}$ of rice seeds (Oryza sativa, var. Pusa Basmati 1121) were sown. Then about 5 rice seedlings (15 days old) were transplanted in each pot. Required intercultural operations were carried out according to necessity. Plants were harvested at maturity. After harvesting, fresh soils were used for subsequent biological properties analysis. Acid phosphatase activity and alkaline phosphatase enzymes were estimated colorimetrically by method suggested by Tabatabai and Bremner (1970). Fluorescein diacetate hydrolysis was estimated as per the method outlined by Green et al., (2006). We analyzed soil properties using analysis of variance (ANOVA) for a complete randomized design. Tukey's honestly significant difference test was used as a post hoc mean separation test (P $<0.05$ ) using SAS 9.1 (SAS Institute, Cary, North Carolina, USA). The Tukey's procedure was used where the ANOVA performed significant.

\section{Results and Discussion}

Microbial activity is a good measure of organic matter turnover in soil since generally more than $90 \%$ of energy flow through microbial decomposer (Heal and MacLean, 1975). Hence activity of acid phosphatase, alkaline phosphatase and fluorescein diacetate in soil was studied in sludge amended soil. 
The acid phosphatase content in soil increased to the tune of $0.1,0.7,1.73,2.18$ and $2.56 \mu \mathrm{g}$ p-nitrophenol g-1 h-1over controls due to addition of sludge of 10,20,30, 40 and $50 \mathrm{~g}$ $\mathrm{kg}^{-1}$, respectively (Table 2). Activity of all the enzymes was reported to enhance significantly due to addition of sludge (Asagiet al., 2007; Frac and Tys, 2011). Soil enzymes are indicators of microbial activities in soils which are often considered as an indicator of soil health and fertility. Alkaline phosphatase also increases over control as $0.87, \quad 1.14,1.91,3.16$ and $3.8 \mu \mathrm{g} \mathrm{p}$ nitrophenol $\mathrm{g}^{-1} \mathrm{~h}^{-1}$ due to sludge addition @ of $10,20,30,40$ and $50 \mathrm{~g} \mathrm{~kg}^{-1}$, respectively (Table 2). Acid phosphatase catalyses reaction at acidic $\mathrm{pH}$ leading to utilization of organically bound $\mathrm{P}$ by microbes. In other words phosphatase enzymes are used by microorganism to excess organically bound $\mathrm{P}$.

Table.1 Initial characteristic of experimental soil and sludge of April, 2015

\begin{tabular}{|c|c|c|}
\hline Parameters & IARI soil & Sludge \\
\hline $\mathrm{pH}_{1: 2}$ & 8.0 & 6.73 \\
\hline $\mathrm{EC}_{1: 2}\left(\mathrm{dS} \mathrm{m}^{-1}\right)$ & 0.24 & 3.92 \\
\hline \multicolumn{3}{|l|}{ Mechanical composition } \\
\hline Clay $(\%)$ & 12.0 & \\
\hline Silt (\%) & 15.0 & \\
\hline Sand (\%) & 73.0 & \\
\hline Texture & sandy loam & \\
\hline Organic carbon $\left(\mathrm{g} \mathrm{kg}^{-1}\right)$ & 3.8 & $13.9^{*}$ \\
\hline Cation exchange capacity $\left(\mathrm{cmol}\left(\mathrm{p}^{+}\right) \mathrm{kg}^{-1}\right)$ & 16.9 & \\
\hline Available $\mathrm{N}\left(\mathrm{mg} \mathrm{kg}^{-1}\right)$ & 94.6 & $1.67 *$ \\
\hline Available $\mathrm{P}\left(\mathrm{mg} \mathrm{kg}^{-1}\right)$ & 8.51 & $1.60 *$ \\
\hline Available $\mathrm{K}\left(\mathrm{mg} \mathrm{kg}^{-1}\right)$ & 139 & $0.18 *$ \\
\hline \multicolumn{3}{|l|}{ DTPA Extractable nutrients } \\
\hline $\mathrm{Fe}\left(\mathrm{mg} \mathrm{kg}^{-1}\right)$ & 4.11 & $0.95 *$ \\
\hline $\mathrm{Zn}\left(\mathrm{mg} \mathrm{kg}^{-1}\right)$ & 2.06 & $1186 * *$ \\
\hline $\mathrm{Cu}\left(\mathrm{mg} \mathrm{kg}^{-1}\right)$ & 1.24 & $94.1 * *$ \\
\hline $\mathrm{Mn}\left(\mathrm{mg} \mathrm{kg}^{-1}\right)$ & 7.26 & $128 * *$ \\
\hline $\mathrm{Ni}\left(\mu \mathrm{kg}^{-1}\right)$ & 118 & $16.5 * *$ \\
\hline $\mathrm{Cd}\left(\mu \mathrm{g} \mathrm{kg}^{-1}\right)$ & 38.3 & $4.75 * *$ \\
\hline $\mathrm{Pb}\left(\mathrm{mg} \mathrm{kg}^{-1}\right)$ & 0.94 & $32.7 * *$ \\
\hline Olsen extractable As $\left(\mu \mathrm{g} \mathrm{kg}^{-1}\right)$ & 9.51 & $2.37 * *$ \\
\hline
\end{tabular}

* Total nutrients (\%) ** Total heavy metal (mg kg-1) 
Table.2 Effect of sludge application on biological properties of soil

\begin{tabular}{|c|c|c|}
\hline $\begin{array}{l}\text { Rates of sludge addition } \\
\qquad\left(\mathrm{g} \mathrm{kg}^{-1}\right)\end{array}$ & $\begin{array}{c}\text { Acid phosphatase } \\
\left(\mu \mathrm{g} p \text {-nitrophenol } \mathrm{g}^{-1} \mathrm{~h}^{-1}\right)\end{array}$ & $\begin{array}{c}\text { Alkaline phosphatase } \\
\left(\mu \mathrm{g} \text { p-nitrophenol } \mathrm{g}^{-1} \mathrm{~h}^{-1)}\right.\end{array}$ \\
\hline 0 (control) & $3.41^{\mathrm{b}}$ & $4.35^{\mathrm{d}}$ \\
\hline 10 & $3.51^{b}$ & $5.22^{\mathrm{c}}$ \\
\hline 20 & $4.11^{b}$ & $5.49^{\mathrm{bc}}$ \\
\hline 30 & $5.14^{\mathrm{a}}$ & $6.26^{\mathrm{a}}$ \\
\hline 40 & $5.59^{\mathrm{a}}$ & $7.51^{\mathrm{a}}$ \\
\hline 50 & $5.97^{\mathrm{a}}$ & $8.16^{\mathrm{a}}$ \\
\hline
\end{tabular}

Fig.1 Change in fluorescein diacetate $\left(\mu \mathrm{g} \mathrm{g}^{-1}\right)$ due to sludge application After harvest of rice over control

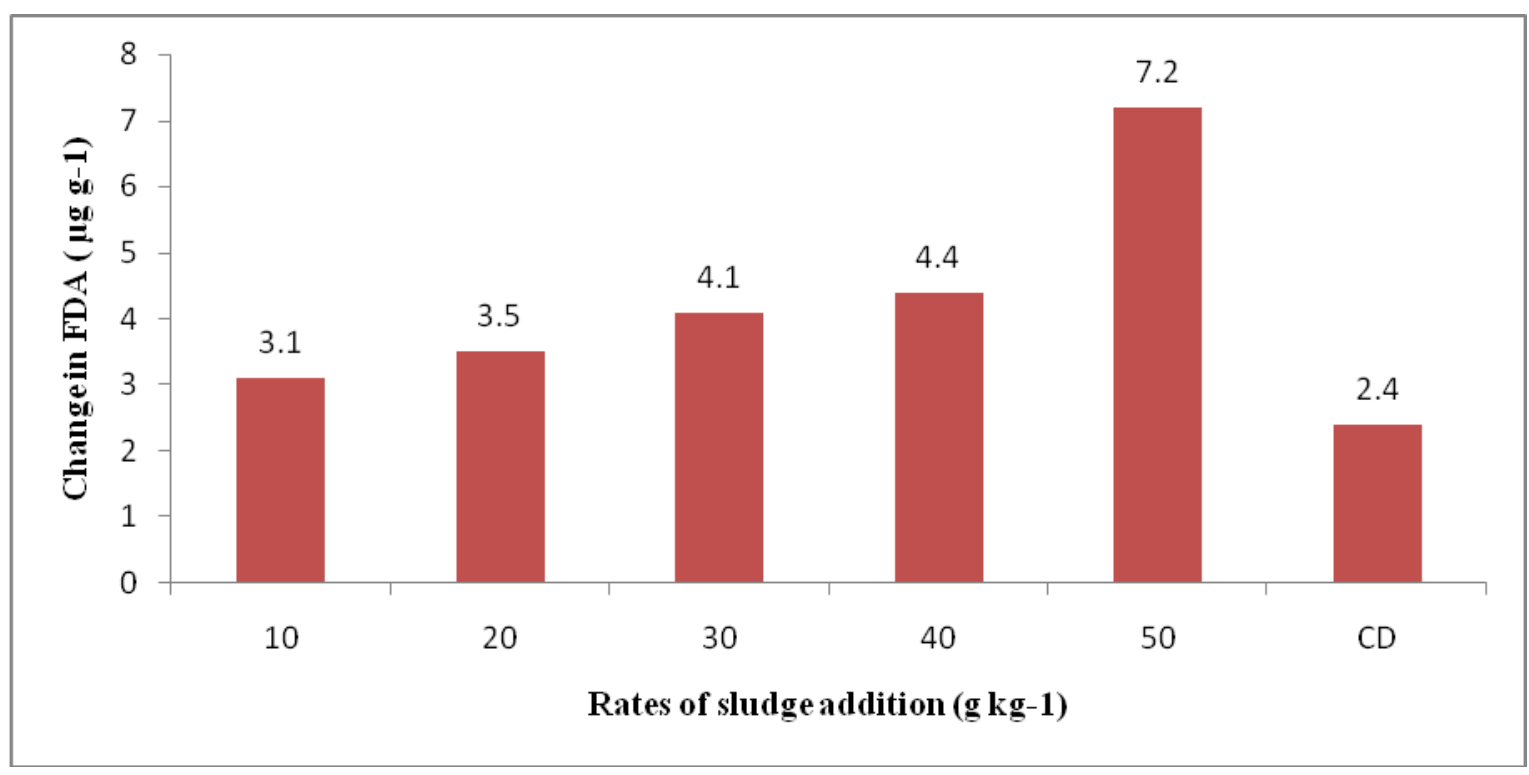

Alkaline phosphatase is hydrolyses enzyme responsible for removing phosphate group from organic compound (Tabatabi, 1982). There was significant increase in Fluorescein diactate content in soil after harvest of rice when sludge was added at the rate of 10, 20, 30,40 and $50 \mathrm{~g}$ kg-1corresponding increased

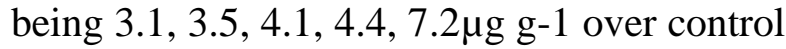
(Figure 1). Fluorescein diacetate has been used to determine amount of active fungi and bacteria in soil (Sodestrom, 1977; Lundgren, 1981). It is hydrolyse by a number of different enzymes such as protease, lipases and asterases. The product of this enzymatic conversion is fluorescein, which can visualize within cells by fluorescein microscopy.
Fluorescein can also be quantified by flurometery or spectrophotometery (Schnurer and Rosswall, 1982). Hence fluorescein diacetate is an indicator of overall activity of decomposer microorganism. In the present study, higher activity of all these enzymes was observed in sludge treated soil may be attributed to readdition of organic matter through sludge, which is turned increase in the population of microbes and stimulated enzymatic activity in soil.

In conclusion, results can be concluded as sludge is a good source of plant nutrients, nitrogen $(\mathrm{N})$, phosphorus $(\mathrm{P})$, potassium $(\mathrm{K})$, sulphur (S) and two important micronutrient 
contents i.e. of zinc $(\mathrm{Zn})$ and iron $(\mathrm{Fe})$ and also helps in improvement in fertility and important biological properties of soil.

\section{References}

Asagi, N., Ueno, H. and Ebid, A. 2007. Effects of sewage sludge applicationon rice growth, soil properties, and $\mathrm{N}$ fate in low fertile paddy soil. Int. J. Soil Sci., 2: 171181.

Bouyoucos, G.J. 1962. Hydrometer method improved for making particle size analyses of soils. Agronomy J., 54: 464-465.

Commodity profile for rice April. 2016. http://agricoop.nic.in/ Admin_Agricoop/ Uploaded File/Rice_Apr15.pdf

CPCB. 2016. Performance evaluation of sewage treatment plants under NRCD. Central Pollution Control Board, Delhi, India.

Datta, S.P., Subba Rao, A. and Ganeshamurthy, A.N. 1997. Effect of electrolytes coupled with variable stirring on soil $\mathrm{pH}$. Journal of the Indian Society of Soil Science 45:185-187.

Doelsch, E., Van de Kerchove, V. and Saint Macary, H. 2006. Heavy metal content in soils of Réunion (Indian Ocean). Geoderma, 134: 119-134.

Frąc, M., and Jezierska-Tys, S. 2011. Agricultural utilisation of dairy sewage sludge: Its effect on enzymatic activity and microorganisms of the soil environment. African J. Microbiol. Res., 5: 1755-1762.

Ghahdarijani, A.J., Kalbasi, M. and Ghehsareh, A.M. 2015. Effect of application of sewage sludge and two synthetic humic acids on selected chemical properties of three soils. Biol. Forum, 7: 344-348.

Golui, D., Datta, S.P., Rattan, R.K., Dwivedi, B.S. and Meena, M.C. 2014. Predicting bioavailability of metals from sludgeamended soils. Environ. Monitoring and Assessment, 186: 8541-8553.

Gray, N.F. 2010. Water technology: an introduction for environmental scientists and engineers (No. Ed. Mtshali 3). IWA Publishing.

Green, V.S., Stott, D.E. and Diack, M. 2006. Assay for fluorescein diacetate hydrolytic activity: optimization for soil samples. Soil Biol. Biochem., 38: 693-701.

Heal, O.W., and MacLean J.S.F. 1975. Comparative productivity in ecosystemssecondary productivity. Unifying Concepts in Ecol., (pp. 89-108).

Jackson, M.I.L. 1973. Soil Chemical Analysis. Prentic Hall (India) Pvt. Ltd. New Delhi.

Latare, A.M., Kumar, O., Singh, S.K. and Gupta, A. 2014. Direct and residual effect of sewage sludge on yield, heavy metals content and soil fertility under rice-wheat system. Ecol. Engi., 69: 17-24.

Lindsay, W.L. and Norvell, W.A. 1978. Development of a DTPA soil test for zinc, iron, manganese and copper. Soil Sci. Society of America J., 42: 421-428.

Lundgren, B. 1981. Fluorescein diacetate as a stain of metabolically active bacteria in soil. Oikos, 36: 17-22.

Martinez, F., Cuevas, C., Teresa, Walter and Iglesias Ingrid. 2002. Urban organic wastes effects on soil chemical properties in degraded semiarid ecosystem. In: Seventeenth WCSS, Symposium No. 20, Thailand. p.1-9.

Mondal, S., Singh, R.D., Patra, A.K. and Dwivedi, B.S. 2015. Changes in soil quality in response to short-term application of municipal sewage sludge in a Typic Haplustept under cowpeawheat cropping system. Environmental Nanotechnology, Monitoring and Management, 4: 37-41.

Mtshali, J.S., Tiruneh, A.T. and Fadiran, A.O. 2014. Characterization of sewage sludge generated from wastewater treatment plants in Swaziland in relation to agricultural uses. Res. Environ., 4: 190199.

Nandakumar, K., Ramamurthy, S., Rajarajan, A. and Savarimuthu, E. 1998. Suitability of Dindigul town's sewage sludge for field application: nutritional perspective. Poll. Res., 17: 61-63. 
Nelson, D.W. and Sommers, L.E. 1982. Total carbon, organic carbon, and organic matter. Methods of soil analysis. Part 2.Chemical and microbiological properties, (methodsofsoilan2), 539-579.

Olsen, S.R., Cole, C.V., Watanabe, F.S. and Dean, L.A. 1954. Estimation of available phosphorus in soils by extraction with sodium bicarbonate. U. S. Department of Agriculture Circular No. 939. Banderis, A.D., D.H. Barter and K. Anderson, Agricultural and Advisor.

Schnürer, J. and Rosswall, T. 1982. Fluorescein diacetate hydrolysis as a measure of total microbial activity in soil and litter. Appl. Environ. Microbiol., 3: 1256-261.

Singh, R.P. and Agrawal, M. 2008. Potential benefits and risks of land application of sewage sludge. Waste Management, 28: 347-358.

Singh, R.P. and Agrawal, M. 2010b. Variations in heavy metal accumulation, growthand yield of rice plants grown at different sewage sludge amendment rates. Ecotoxicol. Environ. Safety, 73: 632-641.
Söderström, B.E. 1977.Vital staining of fungi in pure cultures and in soil with fluoresce in diacetate. Soil Biol. Biochem., 9: 59-63.

Subbiah, B.V. and Asija, G.L. 1956. A rapid procedure for the estimation of available nitrogen in soils. Curr. Sci., 25: 259-260.

Tabatabai, M.A. 1982. Soil enzymes Methods of Soil Analysis Part 2. Chem. Microbiol. Properties, 2: 903-947.

Tabatabai, M.A. and Bremner, J.M. 1970. Arylsulfatase activity of soils. Soil Sci. Society of America J., 34: 225-229.

Tsadilas, C.D., Matsi, T., Barbayiannis, N. and Dimoyiannis, D. 1995. Influence of sewage sludge application on soil properties and on the distribution and availability of heavy metal fractions. Communications in Soil Sci. Plant Analysis, 26: 2603-2619.

Walkley, A. and Black, I.A. 1934. An examination of the degtjareff method for determining soil organic matter, and a proposed modification of the chromic acid titration method. Soil Sci., 37: 29-38.

\section{How to cite this article:}

Anil Kumar Verma, Raj Dev Singh, Brijesh Yadav, Ravi Kumar Meena and Chiranjeev Kumawat. 2017. Effect of Sludge Addition on Biological Properties of Soil under Rice Cultivation. Int.J.Curr.Microbiol.App.Sci. 6(5): 2677-2683. doi: https://doi.org/10.20546/ijcmas.2017.605.300 